\title{
Reoquatia
}

\section{Identiti koperasi pekebun kecil sawit di Malaysia: Satu deskripsi awal}

\author{
Suraiya Ishak ${ }^{1}$, Ahmad Raflis Che Omar ${ }^{2}$, Sarmila Md Sum ${ }^{1}$, Abdullah Sanusi Othman² \\ ${ }^{1}$ Pusat Kajian Pembangunan, Sosial dan Persekitaran, Fakulti Sains Sosial dan Kemanusiaan, Universiti \\ Kebangsaan Malaysia \\ ${ }^{2}$ Pusat Kajian Penciptaan Nilai dan Kesejahteraan Insan, Fakulti Ekonomi dan Pengurusan, Universiti \\ Kebangsaan Malaysia
}

Correspondence: Sarmila Md Sum (sarmila.mdsum@ukm.edu.my)

Received: 25 February 2020; Accepted: 25 June 2020; Published: 29 November 2020

\begin{abstract}
Abstrak
Koperasi adalah entiti yang ditubuhkan bagi mencapai matlamat ahli yang homogenous sifatnya. Secara umumnya, koperasi bertujuan menjaga kebajikan ahli-ahlinya. Namun selari dengan perkembangan semasa entiti koperasi turut berhadapan suasana baharu yang berpotensi memberi kesan kepada identitinya. Selain daripada itu, faktor kontekstual juga berpotensi mewujudkan pola tertentu dalam pengoperasian konsep koperasi. Makalah ini bertujuan mendeskripsi ciri-ciri identiti koperasi pekebun kecil kelapa sawit di Malaysia. Kajian ini telah menggunakan teknik temubual dengan enam buah koperasi di negeri Selangor, Perak dan Johor. Data temubual telah dianalisa dengan kaedah tematik bagi mengenalpasti ciri-ciri identiti koperasi. Penemuan kajian menunjukkan koperasi pekebun kecil kelapa sawit dianggotai oleh pekebun atau peneroka dan generasi kedua dari kalangan mereka. Koperasi mempunyai struktur Ahli Lembaga Koperasi yang dipilih daripada ahli-ahli koperasi dan memiliki autonomi dalam membuat keputusan tanpa campur tangan pihak luar. Perkhidmatan yang ditawarkan adalah cenderung ke arah portfolio perniagaan yang "selamat" dan "rendah risiko". Walau bagaimanapun, koperasi pekebun kecil sawit terlibat menunjukkan pola pengembangan portfolio perniagaan yang tidak lagi tertumpu kepada pelaburan atau aktiviti-aktiviti pasif. Koperasi pekebun kecil kelapa sawit cenderung untuk terlibat dalam aktiviti penjanaan hasil yang lebih berdaya maju. Namun begitu secara keseluruhan, orientasi keusahawanan koperasi menunjukkan trend yang konsisten dengan corak penawaran perkhidmatan yang masih bersifat konservatif dan berhati-hati.
\end{abstract}

Kata kunci: Koperasi, tadbir urus koperasi, orientasi keusahawanan, tingkah laku organisasi pengurusan, pekebun kecil sawit 


\title{
The identity of palm oil smallholders' cooperative in Malaysia: A preliminary descriptive
}

\begin{abstract}
Cooperatives are entities that established to achieve the goals of homogeneous members. Generally, a cooperative aim to protect the well-being of its members. But in line with the current development, a cooperative entity is also facing a new environment that could potentially affect its identity. In addition, contextual factors have the potential to create certain patterns in operationalizing cooperative concepts. This paper aims at describing the identity characteristics of oil palm smallholder cooperatives in Malaysia. This study employed interview techniques with six cooperatives in the states of Selangor, Perak and Johor. The findings of this study show that oil palm cooperatives belong to both farmers and settlers and also their second generations. The cooperative has the structure of a Cooperative Board Member selected from the members of the cooperative and has the autonomy in decision-making without external intervention. The services offered are likely to be towards a "safe" and "low risk" business portfolio. However, the cooperative of smallholders shown a pattern of expanding business portfolios that is no longer focused on investment or passive activities. The oil palm smallholders' cooperatives are increasingly becoming more involved in more productive yields. However, the overall entrepreneurial orientation reflects a consistent trend that offer services with conservative and cautious pattern.
\end{abstract}

Keywords: Cooperative, cooperative governance, entrepreneruial orientation, organziational behavior, management, oil palm small holders.

\section{Pengenalan}

Koperasi mempunyai peranan penting dalam pembangunan ekonomi Malaysia (Mahazril 'Aini, Hafizah \& Zuraini, 2012). Hal ini terbukti daripada sejarah kewujudan koperasi di Malaysia yang berlaku seawal tahun 1922 dengan tujuan menjaga kebajikan penduduk luar bandar dan melindungi mereka daripada eksploitasi. Menurut kajian Mahazril 'Aini, Hafizah and Zuraini (2012), koperasi pertama yang didaftarkan pada tahun 1922 ialah Syarikat Bekerjasama-sama Jimat Cermat dan Pinjaman Wang Pekerja-Pekerja, Jabatan Pos dan Telekom Berhad (kini dikenali sebagai Koperasi Telekom Malaysia Berhad (KOTAMAS) and Koperasi Pos Nasional Berhad (KOPONAS). Berikutnya, koperasi luar bandar yang pertama iaitu Syarikat Kampong Tebuk Haji Musa Berkerjasama-Sama dengan Tanggungan Berhad, Parit Buntar, Krian, Perak telah ditubuhkan pada tahun 1923. Semenjak itu gerakan koperasi di Malaysia telah menunjukkan perkembangan positif seperti pengenalan institusi seperti Maktab Kerjasama Malaysia, Angkatan Koperasi Kebangsaan Malaysia (ANGKASA) dan pelbagai koperasi baharu dalam pelbagai sektor. Kini, pendaftaran koperasi di Malaysia terletak di bawah kuasa Suruhanjaya Koperasi Malaysia melalui Akta Koperasi 1993 (Akta 502) (Suruhanjaya Koperasi Malaysia, 2018). Pada masa kini terdapat sejumlah 14,417 buah koperasi berdaftar di Malaysia dengan bilangan keahlian seramai 6,046,031 orang dan asset terkumpul berjumlah RM143,697.06 (Jadual 1). 
Jadual 1. Perangkaan Koperasi Mengikut Negeri, Jun 2019

\begin{tabular}{clccc}
\hline Bil. & \multicolumn{1}{c}{ Negeri } & Bilangan & Keahlian & Aset (RM juta) \\
\hline 1. & Johor & 1,424 & 411,444 & $1,278.11$ \\
2. & Kedah & 978 & 237,185 & 735.09 \\
3. & Kelantan & 901 & 278,426 & $2,323.28$ \\
4. & Melaka & 473 & 141,011 & 482.50 \\
5. & Negeri Sembilan & 779 & 166,253 & 344.38 \\
6. & Pahang & 1,147 & 244,631 & $1,486.34$ \\
7. & Perak & 1,643 & 309,158 & $1,317.32$ \\
8. & Perlis & 208 & 49,735 & 165.54 \\
9. & Pulau Pinang & 731 & 126,536 & 920.86 \\
10. & Sabah & 1,565 & 270,852 & 764.88 \\
11. & Sarawak & 1,058 & 262,590 & 589.92 \\
12. & Selangor & 1,720 & 548,885 & $1,715.72$ \\
13. & Terengganu & 747 & 226,481 & 649.77 \\
14. & Wilayah Persekutuan & 1,040 & $1,788,979$ & $18,633.39$ \\
15. & Ibu Pejabat & 3 & 983,865 & $112,289.96$ \\
& Jumlah & 14,417 & $6,046,031$ & $143,697.06$ \\
\hline
\end{tabular}

Sumber: Perangkaan Gerakan Koperasi Malaysia Interim 2019.

Koperasi juga memainkan peranan penting dalam pemerkasaan petani tempatan. Hal ini selari dengan Torgerson, Reynolds \& Gray (1997) dan Ortmann \& King (2007) yang menyatakan koperasi pertanian sebagai entiti perniagaan bantu-kendiri yang bebas (independently self-help business entity) yang membantu para petani. Menurut Boland, Hogeland \& McKee (2011), koperasi adalah entiti yang ditubuhkan bagi menjayakan visi perniagaan yang mudah dan melibatkan ahli-ahli yang homogenus. Satu lagi keunikan koperasi ialah pemilik dan pelanggan adalah kumpulan yang sama. Sungguhpun keadaan tersebut dikaitkan sebagai satu kelebihan bagi koperasi pada masa lalu, tetapi keadaan itu telah menjadi cabaran mengurusbagi persekitaran semasa. Umpamanya, untuk bersaing koperasi perlu membuat keputusan yang selari dengan trend pasaran. Walau bagaimanapun tindakan tersebut mungkin tidak boleh dilakukan kerana kekangan menjaga kebajikan dan kepentingan ahli. Sehubungan itu dalam konteks tersebut wujud dua situasi bertentangan, iaitu sebagai pengguna ahli-ahli mahukan keuntungan dalam bentuk kos yang murah; namun dalam konteks sebagai pemilik individu yang sama itu mahukan keuntungan dan dividen yang lebih tinggi. Menurut Ortmann \& King (2007), pembangunan entiti koperasi adalah dibentuk oleh pelbagai faktor dan pengaruh seperti keadaan ekonomi, organisasi pekebun dan polisi awam. Terkini, satu daripada fenomena yang kuat mempengaruhi organisasi koperasi pertanian ialah kebangkitan gerakan Koperasi Generasi Baharu (New Generation Cooperatives atau NGC) yang mulai tercetus semenjak tahun 1988. NGC masih mengekalkan kebanyakkan daripada identititipikal koperasi, namun semakin kuat memberi fokus kepada aktiviti-aktiviti yang bernilai-tambah.

Artikel ini bertujuan mengenalpasti dan menghurai identiti koperasi pekebun kecil sawit di Malaysia. Ini kerana sekalipun koperasi berperanan penting dalam usaha memperkasa sosioekonomi pekebun kecil seperti disebut pengkaji terdahulu (Sarmila et al., 2017; Ojiagu, Onugu \& Uchenna, 2015; Kumar et al., 2015; Sushila et al., 2009; Sushila et al., 2010; Torgerson, Reynolds \& Gray, 1997), masih wujud lompang kajian berkaitan identiti atau ciri-ciri koperasi pekebun kecil sektor kelapa sawit. Perkara ini penting dikaji kerana sektor kelapa sawit merupakan penyumbang penting kepada ekonomi negara. Justeru seluruh institusi dan entiti yang wujud dalam rantaian pengeluarannya harus difahami dengan teliti supaya dapat memperkasakan peranan masing-masing dengan lebih berkesan. Salah satu daripada entiti penting yang ada 
dalam lingkungan pengeluaran hasil sawit pekebun kecil tempatan ialah koperasi. Oleh itu kajian ini dijangka menyumbang kepada pengkayaan ilmu berkaitan koperasi dengan menfokus kepada huraian identiti koperasi pekebun kecil sawit berdasarkan pendekatan kajian kualitatif.

\section{Koperasi}

Sejarah gerakan koperasi dapat diselusuri melalui komitmen padu tokoh reformasi masyarakat iaitu Robert Owen (1771-1858) pada kurun ke-18. Meskipun Owen mempelopori idea koperasi beliau sebenarnya merupakan antara tokoh kapitalis berjaya pada ketika itu. Owen sangat komited menyarankan usaha mereformasi keadaan golongan terpinggir melalui model baharu yang berasaskan kerjasama kolektif dan bantu-kendiri (self help) (Pathak \& Kumar, 2005; Kumar, 1990). Owen turut menegaskan bahawa kelompok miskin tidak sekadar cukup dengan hanya dibantu daripada segi keperluan material, tetapi turut memerlukan pengisian intelektual dan spiritual (melalui jalan pendidikan) supaya dapat mengubah pemikiran mereka kepada bentuk yang lebih maju dan berupaya meningkatkan taraf hidup ke tahap lebih baik. Sehubungan itu projek eksperimen pertama Owen membina model kolektif village of cooperation di kilang tekstil di New Lanark, Scotland.

Model masyarakat kerjasama di New Lanark itu dikenali sebagai Owenite Communities. Pada ketika itu Owen memperkenalkan banyak penambahbaikan di kilang, antaranya tempoh masa bekerja yang lebih singkat, keadaan kerja yang lebih selamat, penubuhan sekolah untuk pelbagai peringkat umur, pendidikan moral, mengubahsuai kediaman, menghentikan amalan buruh kanak-kanak dan menyediakan pelan insurans melalui potongan gaji pekerja. Usaha-usaha tersebut dilakukan dengan tujuan mewujudkan sebuah masyarakat yang dapat menampung diri mereka sendiri dan serba mencukupi (self-sufficient). Walau bagaimanapun projek tersebut tidak dapat bertahan kerana kurang mendapat sokongan pembiayaan daripada sektor awam dan swasta. Berikutan kegagalan projek di New Lanark, Owen telah merantau ke Amerika dan melakukan eksperimen model masyarakat kerjasama beliau di Amerika dengan mewujudkan perkampungan kerjasama dikenali sebagai New Harmony. Walau bagaimanapun projek tersebut juga tidak berjaya kerana individu-individu dalam perkampungan kerjasama New Harmony lebih berminat kepada ganjaran individu dan menjaga kepentingan diri.

Sewaktu Owen di Amerika, idea beliau telah semakin diterima dan diamalkan oleh pejuang kelas pekerja di England. Salah satu daripada Konsep Owen telah berjaya melahirkan sebuah model prototaip koperasi moden yang berjaya iaitu Rochdale Pioneers. Pada tahun 1844 sekumpulan 28 orang pekerja di kilang kapas di bandar perindustrian Rochdale di wilayah Manchester telah menubuhkan perniagaan koperasi moden iaitu Rochdale Equitable Pioneers Society. Pekerja tersebut berhadapan masalah tempat kerja yang teruk, upah rendah dan tidak mampu membeli makanan serta keperluan hidup disebabkan harga yang mahal. Justeru mereka berpakat mengumpul sumber bersama-sama dan bekerjasama memastikan dapat memperolehi keperluan tersebut dengan harga yang lebih rendah. Pada peringkat permulaan koperasi tersebut hanya menyediakan 4 item keperluan asas terpenting iaitu tepung, oatmeal, gula dan mentega (International Cooperative Alliance ${ }^{a}$, 2018). Berikutan itu, Rochdale telah dianggap sebagai bandar kelahiran gerakan koperasi di United Kingdom dan prinsip Rochdale Pioneers telah diterima sebagai peraturan asas koperasi moden seluruh dunia (Pathak \& Kumar, 2005). Prinsipprinsip Rochdale terdiri daripada keahlian terbuka dan sukarela, kawalan demokratik, faedah atas modal yang terhad, dan pembayaran dividen atas pembelian daripada koperasi. Prinsip asas 
Rochdale telah dikemaskini dari masa ke semasa oleh International Cooperative Alliance (ICA) dan akhirnya menjadi sebahagian daripada kandungan Statement on the Co-operative Identity (International Cooperative Alliance ${ }^{b}, 2018$ ). Pada masakini, terdapat hampir tiga juta buah koperasi di dunia dan sekurang-kurangnya 12\% daripada populasi dunia adalah anggota koperasi (International Cooperative Alliance ${ }^{\mathrm{c}}, 2019$ ).

Menurut Somerville (2007), identiti koperasi boleh dicirikan samada dalam terma bentuk institusinya atau nilai-nilainya. Koperasi mempunyai bentuk organisasi dan nilai-nilai yang tersendiri. International Cooperative Alliances (ICA) dalam Statement on the Co-operative Identity semenjak tahun 1995 mendefinisikan institusi koperasi sebagai pertubuhan berautonomi oleh individu-individu yang secara sukarelanyabergabung demi memenuhi kehendak dan aspirasi ekonomi, sosial dan budaya mereka yang serupa menerusi sebuah perusahaan milik bersama dan dikawal secara demokratik. Berdasarkan definisi tersebut, koperasi sebenarnya adalah perniagaan sukarela yang dimiliki dan dikawal oleh ahli-ahlinya sendiri, beroperasi untuk kepentingan ahli dan diurus oleh ahlinya sendiri, berasaskan pertimbangan bukan-untung atau asas kos. Ini bermaksud ia mempunyai identiti diri yang berbeza daripada identiti perniagaan kapitalis. Koperasi bukanlah sebuah organisasi bermotif untung (for-profit) kerana ia mementingkan keperluan atau menyelesaikan masalah kritikal yang dihadapi oleh ahli-ahlinya melalui konsep kerjasama dan penyatuan sumber. Justeru usaha untuk memenuhi keperluan dan kehendak ahli pasti melibatkan pelbagai kos dan kemungkinan kos-kos tersebut tidak dapat dipadan atau dikait secara langsung kepada penjanaan aliran masuk hasil. Ini kerana kos-kos dilibatkan bagi menjalankan aktiviti-aktiviti yang dapat meningkatkan status sosial atau penyediaan kemudahan kepada ahli-ahli tetapi tidak memberi pulangan dalam bentuk pendapatan atau alir tunai masuk bagi koperasi.

Meskipun demikian, koperasi berbeza identitinya dengan organisasi bukan-untung (nonprofit organization) seperti badan-badan kebajikan (Somerville, 2007). Asas penubuhan koperasi ialah semata-mata untuk memberi manfaat kepada ahli-ahlinya samada meliputi sasaran manfaat ekonomi atau pun sosial (Othman et al., 2016). Koperasi tidak bertujuan memenuhi keperluan atau aspirasi masyarakat awam yang bukan ahli. Setiap ahli bersetuju menyumbangkan sumber dan bekerjasama bagi memenuhi matlamat bersama. Sebaliknya, organisasi bukan-untung (notfor-profit) ditubuhkan untuk memberi khidmat kepada pihak lain iaitu sesiapa sahaja dalam kalangan masyarakat awam yang disasarkan sebagai penerima faedah kebajikan. Sumber diterima daripada sesiapa sahaja yang mahu menyumbang secara sukarela bagi menyediakan perkhidmatan atau bantuan kepada kelompok sasaran. Di samping itu peranan ahli koperasi juga berbeza dengan peranan yang dilakukan oleh para sukarelawan atau penderma dalam mana-mana badan kebajikan tulen. Berbeza dengan sumbangan para dermawan sesebuah organisasi kebajikan, penyumbang modal dalam koperasi mempunyai jangkaan tertentu iaitu mengharapkan "ganjaran" bentuk tertentu daripada koperasi untuk manfaat dan kepentingan penyumbang modal atau ahli.

Pada masa yang sama, walau pun koperasi dikaitkan sebagai identiti organisasi "bukanuntung", ia tidak bererti motif untung tidak relevan bagi koperasi. Huraian yang lebih menepati konteks identiti "bukan-untung" bagi koperasi ialah berusaha sedaya upaya menjana pendapatan lebihan (surplus) tetapi dengan kaedah yang tidak mengeksploitasi ahli dan memastikan pendekatan yang diambil memaksimumkan manfaat bagi ahli secara sama rata. Fakta ini disokong oleh Ahmad Bello (2005) yang menegaskan operasi koperasi adalah serupa seperti operasi perniagaan yang lain iaitu perlu beroperasi dengan cekap dan berkesan di pasaran, perlu kepada urustadbir yang baik dan memiliki kemampanan kewangan untuk terus kekal beroperasi. 
Namun perbezaan penting koperasi berbanding entiti perniagaan normal ialah daripada segi individu yang berkaitan dengan koperasi iaitu pemilik, pengurusan dan pelanggan. Dalam konteks entiti perniagaan pemerbadanan, pemilik, pengurusan dan pelanggan adalah tiga pihak yang terasing dan berlainan. Dalam konteks perniagaan milikan persendirian, pemilik dan pengurusan adalah pihak yang sama manakala pelanggan atau pengguna perkhidmatan atau produknya ialah pihak lain. Sebaliknya dalam konteks koperasi pemilik, pengurusan dan pelanggan (pengguna) adalah individu yang sama. Rajah 1 menunjukkan kerangka konseptual yang memandu pelaksanaan kajian.

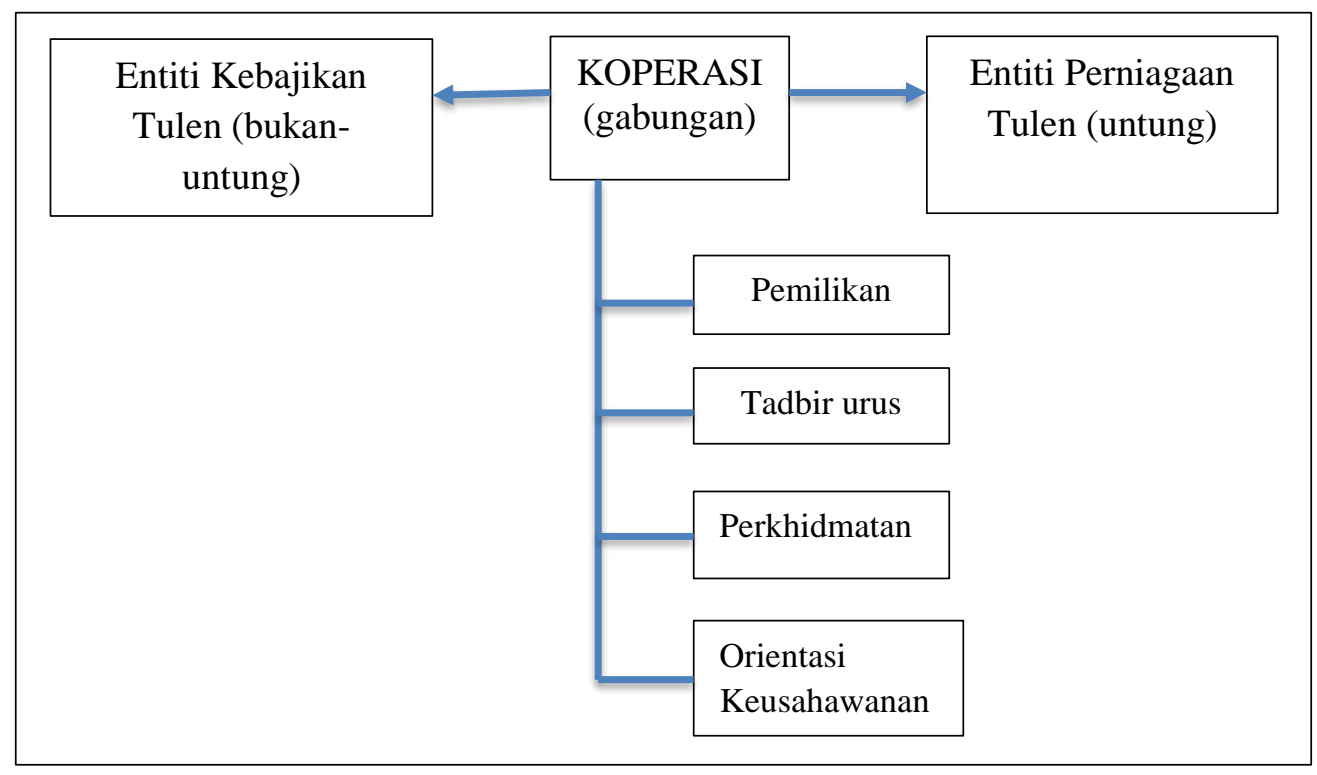

Rajah 1. Kerangka Konseptual Identiti Koperasi Pekebun Kecil Sawit

Berdasarkan perbincangan literatur didapati koperasi adalah entiti unik yang memiliki identiti tersendiri. Berdasarkan Rajah 1, entiti koperasi adalah berada di tengah-tengah kontinum ciri entiti kebajikan tulen dan perniagaan tulen. Namun demkian, kajian khusus yang mendeskripsi identiti koperasi, khususnya koperasi berkaitan pekebun kecil sawit, secara relatifnya masih kurang ditemui. Justeru ia memberi justifikasi kepada perlunya sebuah kajian khusus bagi mengisi jurang kajian yang mampu mendeskripsi identiti koperasi pekebun kecil kelapa sawit dalam persekitaran Malaysia. Kajian sebegini penting kerana sifat atau konteks yang berlainan berpotensi mewujudkan variasi ke atas pengoperasian konsep koperasi.

\section{Metod}

Kajian jenis penerokaan dan deskriptif ini telah menggunakan teknik temubual melibatkan wakil ahli lembaga koperasi (ALK) atau pengurusan dari enam buah koperasi terpilih. Pemilihan koperasi dibuat secara kaedah persampelan tidak berkebarangkalian jenis persampelan bertujuan dengan menghadkan carian informan berpotensi daripada senarai koperasi yang terlibat dalam kata kunci sektor kelapa sawit. Senarai tersebut merupakan senarai koperasi-koperasi yang berdaftar dengan Suruhanjaya Koperasi Malaysia (SKM) dalam sektor pertanian kelapa sawit di negeri Selangor, Johor dan Perak. Penyelidik telah menghubungi pengurusan beberapa koperasi 
sasaran yang ada dalam senarai tersebut untuk tujuan temubual kajian. Justifikasi pemilihan enam buah koperasi terlibat adalah berdasarkan kepada persetujuan pihak pengurusan bekerjasama dalam sesi temubual tersebut. Koperasi A, B dan E adalah berkaitan peneroka skim Felda, manakala koperasi $\mathrm{C}$ dan $\mathrm{F}$ adalah berkaitan pekebun yang menyertai skim tanah Felcra. Koperasi D adalah sebuah koperasi berkaitan pertanian sawit di sebuah kawasan luar bandar.

Pemilihan koperasi adalah berdasarkan kepada status aktif dan kluster pengkelasan "kecil" dan "besar" seperti pengkelasan tertera dalam senarai SKM. Pengkelasan "kecil" dan "besar" adalah berdasarkan saiz perolehan koperasi. Pembabitan kluster "kecil" dan "besar" serentak dapat memastikan wujudnya variasi dalam pemerhatian model koperasi. Maklumat informan ditunjukkan seperti dalam Jadual 2.

Jadual 2. Maklumat Informan

\begin{tabular}{lllcc}
\hline Bil. & Koperasi & Jawatan dalam koperasi & Latar belakang ahli & Kluster \\
\hline 1. & Koperasi A & Responden 1: Pengerusi & Peneroka Felda & Kecil \\
2. & Koperasi B & Responden 2: Pengerusi & Peneroka Felda & Kecil \\
3. & Koperasi C & Responden 3: Pengerusi & Peserta Felcra & Besar \\
4. & Koperasi D & Responden 4: Pengerusi & Orang Awam Tempatan & Tiada maklumat \\
5. & Koperasi E & Responden 5: Setiausaha & Peneroka Felda & Besar \\
6. & Koperasi F & Responden 6: Pengurus & Peserta Felcra & Kecil \\
\hline
\end{tabular}

Informan yang mewakili setiap koperasi adalah terdiri daripada ahli lembaga pengarah atau pengurusan daripada enam koperasi terpilih. Soalan temubual berstruktur telah dibina bagi memandu proses temubual bagi mengawal keseragaman soalan yang dikemukakan kepada responden. Panduan temubual ditunjukkan dalam Jadual 3.

Jadual 3. Panduan Soalan Temubual

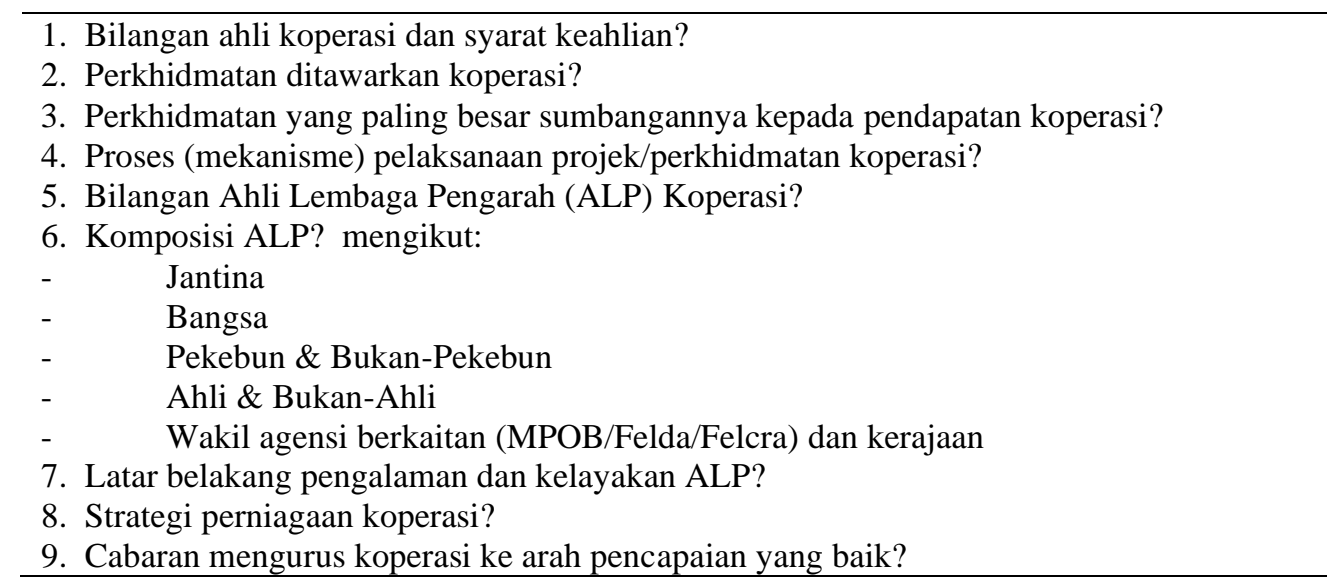

Sesi temubual telah berlangsung selama 2 jam bagi setiap informan di premis pejabat informan di antara bulan April hingga Jun 2018. Temubual tersebut telah dirakam dan kemudiannya ditranskrip secara bertulis. Analisis kandungan telah dilakukan ke atas maklumat temubual bagi menghasilkan rumusan mengenai sifat setiap model perniagaan (business model) yang diamalkan oleh koperasi terlibat pada dimensi tertentu merangkumi pemilikan, urustadbir, perkhidmatan dan orientasi keusahawanan. Kaedah tematik telah digunakan bagi mengenalpasti 
ciri-ciri identiti koperasi daripada kandungan transkrip temubual. Proses penghasilan tema telah dilakukan sejajar dengan langkah prosedur sistematik Braun and Clarke's (2006).

\section{Hasil kajian dan perbincangan}

Analisis identiti koperasi pekebun kecil sawit dibahagikan kepada empat dimensi iaitu aspek pemilikan, tadbir urus, perkhidmatan ditawarkan dan orientasi keusahawanan.

\section{Pemilikan}

Salah satu ciri identiti koperasi yang utama ialah pemilikan bersama oleh individu yang berkongsi ciri atau matlamat yang sama. Pemilikan kolektif koperasi didapati menerusi sumbangan modal atau saham minima dalam koperasi. Ini diperolehi menerusi temubual berikut:

"Lebih kurang 220 orang (iaitu bilangan ahli terkini)... Buat masa ini peneroka sahaja. Termasuk dengan generasi kedua”

(Koperasi A: Responden 1)

"Kita ada 515 yang terbaru...Peneroka majoriti Melayulah, ada dua India dan satu Cina. (Anak-anak peneroka) termasuk sekali. Sini nak masuk (generasi) ketiga dah... Peneroka, peneroka yang bermastautin, yang ada kepentingan dalam kawasan operasi koperasi"

(Koperasi B: Responden 2)

"hanya peserta koperasi FELCRA dan juga anak peserta itu sendiri. (Anak yang layak menjadi ahli) Semua anak. Selama mana dia peserta FELCRA lah dan dia tak keluar dari FELCRA... Kalau nak keluar (dari FELCRA), koperasi akan keluarkan juga keahlian termasuk (keahlian) anak sekali, tu dari segi syarat pertama.."

(Koperasi C: Responden 3)

“...Kita ada 564 (ahli). Semua peneroka, (itu) wajib..... Daripada 564, ada 8 orang India”

(Koperasi E: Responden 5)

Naratif ini menunjukkan koperasi pekebun kecil dianggotai oleh pekebun sawit dan anakanak (generasi kedua) yang bermastautin atau memiliki kepentingan sawit dalam kawasan operasi koperasi. Walau bagaimanapun, keahlian koperasi pekebun kecil terlibat tidak dibuka kepada isteri peneroka. Terdapat koperasi yang turut membuka keahlian kepada kakitangan koperasi dengan syarat mereka masih berkhidmat dengan koperasi seperti bukti berikut:

"kakitangan boleh diterima menjadi ahli koperasi. Dengan syarat minima tempoh bekerja 2 tahun dan disahkan jawatanlah. Tapi apabila staf tu berhenti, keanggotaan (mereka) pun akan tamat"

(Koperasi C: Responden 3) 
Bagi konteks koperasi D, syarat menjadi ahli terbuka kepada penduduk tempatan yang melabur sekurang-kurangnya RM100 dalam saham koperasi. Walau bagaimanapun pengurusan koperasi telah meletakan sekatan had maksimum pelaburan bagi seorang ahli iaitu setakat RM2,000 sahaja:

"Syarat nak jadi ahli minima dia RM100 melabur. Dulu kita tak limit. Dulu ramai melabur banyak-banyak, ada RM10,000 semua tu. So kita limit kan RM2,000 sahaja. Itu pun bayaran dividen kita dalam RM80,000 (kadar 10 peratus)"

(Koperasi D: Responden 4)

"Dia mula-mula dulu memang (terbuka keahlian) kepada semua atau orang daerah sini saja. Undang-undang kecil dia lah dan kena ada kebun. Kemudian kita buka kepada siapa-siapa sahaja”

(Koperasi D: Responden 4)

Amalan membuka keahlian kepada masyarakat yang lebih luas memperlihatkan usaha koperasi untuk meningkatkan bilangan ahli dan dana koperasi. Ini bermaksud sesiapa sahaja yang menyumbang syer akan diterima sebagai ahli. Pada masa yang sama koperasi meletakkan sekatan had maksimum pelaburan bagi memastikan keadilan agihan manfaat kepada semua ahli dan mengelakkan monopoli oleh ahli yang mempunyai lebih keupayaan melabur. Jadual 4 menunjukkan ringkasan bilangan ahli, syarat keahlian, saham minimum per ahli dan jumlah saham terkumpul koperasi terlibat.

Jadual 4. Keahlian Koperasi

\begin{tabular}{llrr}
\hline \multicolumn{1}{c}{$\begin{array}{c}\text { Bilangan ahli (sehingga } \\
\text { tarikh temubual) }\end{array}$} & \multicolumn{1}{c}{ Syarat Keahlian } & Modal (RM) & $\begin{array}{r}\text { Anggaran saham } \\
\text { terkumpul }\end{array}$ \\
\hline Koperasi A (220 Ahli) & Peneroka \& waris & RM200 seorang & 231,836 \\
Koperasi B (515 Ahli) & Peneroka \& waris & RM200 seorang & 84,221 \\
Koperasi C (1,888 Ahli) & Peserta \& waris & Tiada maklumat & $4.717,288.00$ \\
Koperasi D (881 Ahli) & Sesiapa sahaja dan melabur minima & RM100 & 803,819 \\
& RM100 saham koperasi (had & & \\
& maksimum RM2,000) & Tiada maklumat & $450,414.00$ \\
Koperasi E (564 Ahli) & Peneroka \& waris & RM1000 & 575,000 \\
\hline
\end{tabular}

Berdasarkan Jadual 4, didapati modal bagi operasi koperasi diperolehi daripada sumbangan ahli-ahli dalam bentuk saham keahlian. Hal ini menepati ciri identiti koperasi yang dinyatakan dalam Statement on the Co-operative Identity (ICA) iaitu gabungan sukarela ahli-ahli bagi mencapai kehendak dan aspirasi ekonomi, sosial dan budaya menerusi perusahaan yang dimiliki secara bersama dan kawalan demokratik. Justeru ahli-ahli telah berkongsi sumber mereka bagi mewujudkan perusahaan yang bertujuan menjaga kepentingan mereka bersama.

\section{Tadbir Urus}

Secara umumnya, koperasi yang terlibat dalam kajian ini mempunyai struktur urustadbir tersendiri yang diterajui sekumpulan ahli lembaga koperasi (ALK) yang dipilih daripada ahli-ahli 
semasa mesyuarat agung. Secara keseluruhannya, ALK koperasi mempamerkan autonomi dan kebebasan untuk bertindak mewakili kepentingan koperasi dan ahli-ahlinya. Dalam konteks koperasi pekebun kecil sawit yang berkaitan agensi Felda dan Felcra, didapati wakil agensi induk, tidak menganggotai badan ALK koperasi. Sebaliknya wakil tersebut hanya hadir untuk menyampaikan maklumat terkini kepada koperasi supaya dapat dihebahkan kepada ahli secara meluas dan juga mendengar sebarang permasalahan ahli yang diajukan kepada koperasi. Ini dibuktikan menerusi petikan temubual dengan responden koperasi $\mathrm{F}$.

"Ahli lembaga sendiri kebanyakan adalah peserta sendiri. Sebab itu ahli lembaga kami tidak menetap di office. Dia sukarela. Tapi bila melibatkan keputusankeputusan semua, memang ahli lembaga akan datang untuk berbincang dalam mesyuarat"

(Koperasi F: Responden 6)

"FELCRA adalah penasihat. Setiap kali mesyuarat mesti ada FELCRA untuk memaklumkan apa-apa perkembangan terbaru, apa-apa aktiviti yang melibatkan kita bersama. (Tetapi) dia (iaitu wakil FELCRA) tidak duduk dalam struktur koperasi. Sebab pengerusi kami, bendahari, lembaga semua adalah peserta itu sendiri"

(Koperasif F: Responden 6)

Selain daripada itu, terdapat juga keadaan di mana wakil kepada agensi induk dilantik sebagai penaung atau yang dipertua. Struktur ini merujuk kepada konteks koperasi pekebun kecil berkaitan FELDA:

"(Pegawai FELDA) Jadi Yang Dipertua ajelah, pengurus. Bawah pengurus, ada Pengerusi"

(Koperasi A: Responden 1)

"Lembaga kita 12 orang... (Soalan bertanya ada lantik Pengurus FELDA sebagai ALK?) Tak ada”.

(Koperasi B: Responden 2)

"Di sini dipanggil timbalan pengurus besar FELCRA Wilayah XXXX yang kami lantik sebagai yang dipertua koperasi. Dan dia akan hadirlah dalam mesyuarat bulanan koperasi tu dan dia akan bagi nasihat. Macam kalau kami terlajak ke, dia akan tekan brek. Tapi dia tak mempengerusikan mesyuarat. Yang pengerusikan mesyuarat adalah pengerusi sendiri".

(Koperasi C: Responden 3)

“(Pengurus FELDA sebagai) YDP, dalam undang-undang kecil kita. Macam pengurus Felda."

(Koperasi D: Responden 4) 
Justeru dapat difahami bahawa penglibatan wakil agensi induk hanya sebagai penasihat atau tempat rujukan bersesuaian dengan sifat koperasi yang menjadi perantara antara agensi dan pekebun. Jadual 5 menunjukkan perincian komposisi ALK koperasi terlibat.

Jadual 5. Ahli Lembaga Pengarah Koperasi

\begin{tabular}{|c|c|c|c|}
\hline Koperasi & Saiz ALK & Jantina & Ciri pengarah \\
\hline Koperasi A & 12 orang & Semua lelaki & Peneroka skim \\
\hline Koperasi B & 12 orang & 11 lelaki \& 1 perempuan & Peneroka skim \\
\hline Koperasi C & 12 orang & Semua lelaki & $\begin{array}{l}10 \text { Peserta skim ; } 2 \text { anak peneroka } \\
\text { (generasi kedua) }\end{array}$ \\
\hline Koperasi D & 9 orang & Semua lelaki & - \\
\hline Koperasi E & 12 orang & 10 lelaki \& 2 perempuan & Peneroka skim \\
\hline Koperasi F & 12 orang & 10 lelaki \& 2 perempuan & Peserta skim \\
\hline
\end{tabular}

Berdasarkan Jadual 5, lima daripada enam buah koperasi mempunyai keanggotaan ahli lembaga pengarah dalam bilangan yang genap dan seramai 12 orang. Hanya Koperasi D sahaja yang mempunyai bilangan keahlian ALK yang ganjil iaitu sembilan orang. Dalam konteks undian majoriti, keanggotaan ALK yang genap menyebabkan majoriti mudah lebih sukar diperolehi berbanding bilangan keanggotaan yang ganjil. Sehubungan itu ia berpotensi menjadi antara faktor yang menyebabkan sesuatu keputusan atau persetujuan sukar dicapai dalam mesyuarat ALK. Kebanyakan ahli lembaga pengarah koperasi kajian terdiri daripada golongan lelaki. Hal tersebut berkemungkinan dipengaruhi oleh corak penyertaan ahli yang mensyaratkan peneroka dan anak-anak dan tidak termasuk isteri peneroka. Di samping itu menurut pengalaman Koperasi A, kesibukan ahli lembaga wanita yang memegang jawatan lain dalam Jawatankuasa Peneroka Wati (JPW) menyebabkan mereka tidak dapat melibatkan diri dalam mesyuarat ALK koperasi. Hal tersebut dibuktikan melalui temubual berikut:

"Dulu pernah berlaku dalam pengurusan semua lelaki, seorang perempuan. Masa mesyuarat pun dia sibuk. dengan aktiviti JPW. Kalau boleh kita nak tiada tugas supaya senang panggil untuk mesyuarat."

(Koperasi A: Responden 1)

Keadaan itu menunjukkan golongan wanita turut diberi peluang menganggotai ALK dan lazimnya diberi kepada individu yang aktif dalam kelompok wanita terlibat. Justeru ia menjelaskan situasi kesibukkan pengarah wanita tersebut sehingga tidak dapat memperuntukkan masa menghadiri mesyuarat ALK. Di samping itu, pengalaman Koperasi F juga menunjukkan ALK wanita dilantik daripada individu yang memiliki latar belakang pendidikan dan kerjaya yang secara relatifnya lebih baik.

"Ya, bendahari kami Hajah nor (nama samaran), guru besar sekolah rendah Sungai XXX. Pn. Lim (nama samaran) pula bekas cikgu sekolah menengah Tanjung ZZZ"

(Koperasi F: Responden 6)

Justeru berdasarkan konteks keanggotaan ALK dalam Koperasi A dan F dirumuskan pengarah wanita telah dilantik daripada individu yang menonjol keupayaan mereka, disebabkan kekerapan melibatkan diri dalam aktiviti masyarakat setempat (Koperasi A) atau pengalaman 
kerjaya/pendidikan (Koperasi F). Pelaksanaan operasi harian dilakukan oleh ALK secara langsung dengan melantik unit-unit pelaksana yang dikenali dengan nama biro, jawatankuasa dan sektor.

"Dalam kaedah pengurusan, kita ada lantik pengerusi biro-biro. Kita ada Biro Perumahan, Biro Pengurusan. Dalam mesyuarat mereka beri laporan”.

(Koperasi B: Responden 2)

"Di sini kami wujudkan sektor-sektor. Ada sektor peruncitan, sektor perlandangan, dan dalam ALK ada staf-staf yang terlibat. Ahli lembaga ini akan memantau. Setiap 3 bulan kami akan buat mesyuarat. Kalau koperasi lain mungkin ada biro, kami di sini wujudkan sektor dan diketuai oleh ahli lembaga itu sendiri. Dalam satu sektor ada 3 lembaga yang jaga. Dia akan monitor dan laporan akan dibawa ke mesyuarat lembaga. Dari situ dia akan pantau, contohnya ada sektor berlaku penurunan atau masalah supplier maka ALK akan tahu dan bagi nasihatlah...... Setengah koperasi kecil lembaga sendiri buat kerja. Lembaga jaga akaun, lembaga jaga kedai, di sini tidak begitu”

(Koperasi C: Responden 3)

"Kita ada jawatankuasa dia. Macam (hal) pejabat (dan) stesen minyak, di bawah saya (ada) 3 orang... Kemudian kita ada orang untuk buat pengurusan akaun kedai semua"

(Koperasi D: Responden 5)

Berdasarkan maklumat temubual didapati ALK terlibat secara langsung dalam pengurusan operasi dengan dibantu oleh beberapa pekerja yang dikelompokkan di bawah unit dan pemantauan lembaga pengarah yang telah dipertanggungjawabkan. Pembuatan keputusan bagi operasi perniagaan koperasi secara relatifnya agak rumit kerana melibatkan lebih ramai individu. Sebagai contoh ada keputusan telah dicapai dalam perbincangan ALK dan ahli, namun tidak dapat dilaksanakan kerana ada antara ahli pengarahnya yang tidak bersetuju atau bersikap konservatif dan sangat berhati-hati. Ini dibuktikan menerusi pengalaman responden berikut:

"Kertas kerja tu berbulan-bulan saya buat, pergi sana pergi sini, akhirnya tak berjaya. Bendahari seolah-olah dia lagi besar daripada saya (pengerusi koperasi). Banyak yang tak boleh. Tandas koperasi pun perlu baiki. ALK kita sudah luluskan, cuma bila keluarkan Bendahari banyak Tanya itu ini."

(Koperasi A: Responden 1)

"kadang-kadang koperasi tak berani ambil risiko. To be honest koperasi hakmilik peserta.... ahli lembaga risau untuk ambil risiko sebab kalau rugi tak boleh nak jawab dengan peserta. Sebab itu tak berani ambil risiko. Yang penting tak ada rugi dan peserta pun tak boleh persoalkan. Maknanya kami maintain sahaja."

(Koperasi F: Responden 6) 
Akibatnya, perancangan melibatkan koperasi tergendala atau tidak terlaksana seperti dirancang. Ini menyebabkan peluang penjanaan hasil terlepas disebabkan kesukaran melaksanakan keputusan penting.

\section{Perkhidmatan}

Dimensi kedua melibatkan perkhidmatan yang ditawarkan oleh koperasi. Koperasi secara umumnya menjalankan tugas atau peranan yang hampir sama dengan perniagaan buah sawit (fruit dealer atau FD) swasta. Walau bagaimanapun skop perkhidmatan yang ditawarkan adalah terhad berbanding yang ditawarkan FD swasta. Kajian mengenai FD sawit di Malaysia dirujuk secara langsung kepada kajian Suraiya et al. (2016); Ahmad Raflis et al. (2016); dan Suraiya et al. (2017).

Dalam konteks koperasi dibawah skim FELDA dan FELCRA, perkhidmatan penting yang ditawarkan adalah sebagai jentera pelaksana atau perantara di antara agensi induk dan peneroka atau peserta. Koperasi menerima kontrak seperti membaja, meracun dan mengangkut buah sawit daripada agensi induk dengan bayaran tertentu. Hal tersebut dibuktikan melalui temubual berikut:

"Baja memang Felda bagi. Kontrak membaja juga dari kita (merujuk kepada koperasi). Kita yang membaja, mengait dan angkut"

(Koperasi A: Responden 1)

"Kita tak jualan input pertanian seperti baca dan racun, semua dibekalkan oleh pihak pengurusan Felda. Cuma nak membaja koperasi yang ambil tender tu."

(Koperasi B: Responden 2)

Secara umumnya koperasi mempunyai jaminan pendapatan apabila agensi induk memberi kontrak berkaitan pengurusan ladang kepada koperasi. Ini dapat dibuktikan melalui petikan temubual dibawah:

"Jadi apa-apa kerja yang melibatkan ladang di XXXX mesti melalui koperasi, jadi koperasi ada income.”

(Koperasi F: Responden 6)

Meskipun bertindak sebagai agen atau mendapat kontrak kerja-kerja ladang daripada pihak agensi induk, namun koperasi-koperasi tersebut masih kekal mempunyai autonomi sendiri di mana pengurusan koperasi bebas membuat keputusan berkaitan koperasi tanpa campur tangan agensi induk. Agensi induk dan koperasi-koperasi tersebut berdiri sebagai entiti-entiti berasingan dan berhubung sebagai rakan kerjasama dalam jaringan antara mereka. Koperasi pekebun kecil terlibat turut menawarkan perkhidmatan lain dalam skop aktiviti perniagaan bukan berkaitan sawit seperti penyewaan bangunan, stesen minyak dan bas sekolah. Ini bermaksud perkhidmatan yang ditawarkan oleh koperasi adalah bersifat pelebaran portfolio secara horizontal di mana terdapat perniagaan berkait sawit dan bukan sawit sebagai sumber penjanaan hasil. Manakala dalam konteks perniagaan orang tengah yang dikelola oleh FD swasta, perkhidmatan mereka adalah lebih pelbagai tetapi hanya dalam skop aktiviti berkaitan sawit sahaja atau pelebaran 
portfolio secara vertikal seperti perkhidmatan mengurus kebun, pengangkutan buah sawit, rem sawit dan jualan input pertanian.

Berbeza dengan perniagaan FD, kebanyakan koperasi pekebun kecil tidak memberi perkhidmatan kredit tunai kepada ahlinya. Meskipun terdapat dua koperasi yang memberi kredit tunai kepada ahli-ahlinya, namun jumlah pinjaman yang diberi adalah kecil dan/atau dengan kadar faedah tertentu yang lebih rendah berbanding kadar faedah pasaran. Hal ini dapat diperhatikan daripada Koperasi A dan C.

"Tak ada (beri kredit tunai). Cuma kalau ada orang nak pinjam seratus dua tu kita bagilah. Kita bagi kuasa kepada Bendahari tadi untuk bagi. Kalau duit saham dalam koperasi ada 500 dia tak boleh bagi pinjam lebih 500. Tu cagarannya"

(Koperasi A: Responden )

Dalam kes koperasi A, jumlah pinjaman adalah bergantung kepada saham ahli dalam koperasi. Pinjaman tersebut adalah bebas faedah di mana pekebun hanya perlu membayar balik amaun prinsipal yang dipinjam. Manakala dalam kes koperasi C, nilainya adalah lebih besar dan dikenakan kadar faedah pada kadar 3.55 peratus.

"kami ada sediakan pembiayaan anggota, pembiayaan mudah. Yang kami ambil kadar 3.55 peratus sahaja, maknanya kadar pulangan rendah. Bayar dengan cara kami potong dari elaun sara hidup. Maksimum (jumlah pembiayaan yang diberi) setakat ini ialah RM3,500. Dipanggil pinjaman mini atau mikro. InshaaAllah akan dikembangkan lagi. Sebab anak anggota kami ramai dalam 300 orang, ramai yang professional. Ada yang engineer, cikgu, jadi kami ingat kami nak kembangkan dan kami akan kenakan komisyen"

(Koperasi C: Responden 3)

Berdasarkan analisis kajian didapati dalam keadaan persaingan pasaran yang semakin kompetitif, koperasi bakal berhadapan dengan persaingan bukan sahaja dalam kalangan koperasi tetapi juga daripada pemain swasta seperti fruit dealer (FD). Sekiranya pengurusan koperasi tidak responsif kepada tekanan persekitaran, maka keupayaan koperasi dalam memenuhi keperluan ahli-ahli akan menjadi semakin tidak relevan dalam jangka masa panjang. Entiti swasta yang lebih cekap dalam mengurus kos dan peka terhadap keperluan pekebun sekitar akan menarik ahli-ahli koperasi untuk berurusan dengan mereka berbanding koperasi. Secara rasionalnya individu lebih terdorong untuk berurusan dengan pihak yang dapat memberi lebih keuntungan kepada mereka sekalipun pihak tersebut adalah orang luar. Hal ini dapat difahami melalui kenyataan responden berikut:

"Kalau anggota tak support atau kalau tiba-tiba dia boikot, tak nak isi minyak contohnya, walaupun sini satu saja stesen minyak yang ada, tapi mereka sanggup pergi jauh, koperasi (dalam keadaan tersebut) tak boleh buat bisnes"

(Koperasi C: Responden 3) 
"Kedai baja racun ada lah. Kita simpan racun semua. Kita dulu ada bisnes tu. Tapi tak jalan. Fotostat pun ada, tapi sebab ramai orang buat. Tak jalan juga. Persaingan. Tu lah tumpuan kita (hanya) kepada ladang”

(Koperasi E: Responden 4)

\section{Orientasi Keusahawanan}

Orientasi keusahawanan koperasi memperlihatkan sikap terhadap risiko yang konservatif. Secara keseluruhannya mereka mahu terlibat dalam sesuatu yang "selamat" dan rendah atau tiada risiko langsung.

"Saya cadangkan koperasi beli rumah kedai. Saya siap buatkan kertas kerja tapi ada yang bimbang siapa nak sewa. Saya kata beli dulu, bila dah terlepas peluang, BSN tanya ada rumah kedai tak untuk disewa? Kalau BSN sewa buat cawangan, sampai bila-bila duit situ..."

(Koperasi A: Responden 1)

"Dulu kami ada ambil kontrak memetik buah. Tapi sekarang kami tak ambil sebab tak cukup pekerja. Pekerja Indonesia ni susah sikit nak ambil, kadang kos tinggi, ada yang lari, jadi kami tak nak ambil risiko. Sebab itu kami ambil mengangkut buah sahaja"

(Koperasi D: Responden 6)

Ini menunjukkan koperasi terlibat secara umumnya masih berpegang kepada teras identiti sebagai "organisasi bukan untung" (non profit) yang bertujuan menjaga kepentingan ahli. Walau bagaimanapun terdapat koperasi yang menunjukkan orientasi keusahawanan yang agak tinggi seperti Koperasi C, D dan E. Hal demikian kerana pengurusan koperasi secara relatifnya menonjolkan sikap taktikal, merebut peluang dan berstrategi dalam memastikan keuntungan yang optimum dan bersesuaian dengan koperasi. Ini diperhatikan daripada petikan temubual berikut:

"Racun tu kita beli banyak. Kita ambil 10-15 peratus margin. Kalau kita beli 45, kita jual 55. Kita ambillah dalam RM10. Baja pun sama. Kita kena ambil kiralah kos penghantaran semua. Kita bukan ambil sangat keuntungan. Perkhidmatan sajalah.

(Koperasi D: Responden 4)

"Di sini ada yang buat IKS, ada buat kerepek, bahulu, memang kami ambil direct dari owner dan memang kami jual di sini (koperasi). Dan kami juga ada supply ke luar. Jadi macam one stops centre lah. Anggota atau peserta tak perlulah penat-penat pergi ke Ipoh sebab kami dah ada rangkaian. Kami hello je, nak berapa, kami hantar, sebab kami ada lesen borong, kami supply ke koperasi lain. Kami juga supply kepada anggota yang ada buka kedai runcit. Kami bagi kredit juga”.

(Koperasi C: Responden 3) 
Berdasarkan huraian ini, koperasi-koperasi pekebun kecil tersebut masih mengekalkan identiti sebagai sebuah koperasi. Kebajikan dan keperluan ahli masih menjadi keutamaan. Walau bagaimanapun seiring dengan perubahan pasaran dan konteks pekebun kecil sawit masakini, strategi koperasi menunjukkan sifat yang semakin agresif dan menjurus kepada tingkah laku perniagaan swasta. Justeru ia menepati pandangan Ahmad Bello (2005) yang menyatakan sekalipun koperasi ialah organisasi bukan untung, namun ia tidak bererti motif untung tidak relevan bagi koperasi. Sebaliknya, koperasi masih perlu perlu kepada pelaksanaan urustadbir yang cekap dan berkesan seperti entiti perniagaan yang lain. Hal yang demikian penting bagi menjamin keupayaan koperasi kekal dan mampu memberi khidmat terbaik kepada ahli dalam jangka masa panjang khususnya dalam era gerakan Koperasi Generasi Baharu (New Generation Cooperatives) yang menfokus kepada aktiviti yang bernilai tambah.

\section{Kesimpulan}

Koperasi adalah entiti yang mempunyai ciri tersendiri. Secara umumnya, koperasi pekebun kecil sawit masakini mempunyai identiti sebagai sebuah koperasi yang bergerak atas prinsip koperasi yang berasaskan prinsip Rochdale. Walau bagaimanapun, dalam mencapai matlamat ekonomi dan sosial penubuhannya, tingkah laku koperasi tersebut telah menunjukkan anjakan pemikiran ke arah urustadbir yang profesional dan berorientasikan gerak usaha keusahawanan. Koperasi pekebun kecil telah melebarkan portfolio perniagaan dengan tidak hanya membataskan kepada pelaburan pasif seperti pelaburan dalam saham tertentu lagi. Sebaliknya koperasi pekebun kecil itu telah terlibat dengan portfolio pelaburan yang bersifat risiko diperhitungkan (calculated risk) iaitu dengan menceburi perniagaan bukan berkaitan sawit yang selamat. Namun identiti koperasi yang asas - iaitu memberi manfaat dan menjaga kebajikan para ahlinya, masih kuat membentuk identiti koperasi-koperasi yang dikaji. Implikasi teori daripada kajian ini ialah koperasi pekebun sawit masih merupakan entiti yang berada di tengah-tengah kontinum matlamat kebajikan dan untung. Meskipun aspek kebajikan masih kekal menjadi keutamaan bagi koperasi berkaitan sawit, wujud keperluan untuk pengurusan yang lebih berdaya saing demi kesinambungan objektif koperasi. Implikasi pengurusan ialah ahli lembaga koperasi yang lebih dinamik diperlukan bagi meningkatkan pencapaian koperasi ke tahap yang lebih baik. Pemerkasaan kompetensi ahli lembaga koperasi dapat meningkatkan kualiti pengurusan prestasi koperasi selari dengan perubahan semasa. Kajian akan datang disaran untuk melanjutkan penerokaan ini ke atas skop koperasi yang berbeza bagi meneliti sejauhmana identiti tersebut dipengaruhi oleh ciri-ciri keahlian dan komposisi lembaga pengarahnya. Di samping itu kajian akan datang disaran melakukan kajian bagi meneliti perspektif kepemimpinan tertinggi koperasi pekebun sawit dalam memperihal prestasi koperasi secara lebih mendalam kerana ia menentukan halatuju dan cara pengurusan streategik koperasi.

\section{Penghargaan}

Kajian ini dibiayai oleh geran penyelidikan Kursi MPOB-UKM EP 2017-055. 


\section{Rujukan}

Ahmad Bello, D. (2005). The role of cooperative societies in economic development. Munich Personal RePec Archive (M|PRA). Paper no. 23161. Retrieved from http://mpra.ub.unimuenchen.de/23161/

Ahmad Raflis Che Omar, Suraiya Ishak, Abd Hair Awang, Mohd Yusof Hussain, Novel Lyndon \& Abdullah Sanusi Othman. (2016). Orang tengah dalam rantaian pengeluaran pekebun kecil kelapa sawit di Malaysia: Satu penemuan awal dari Perak. Geografia-Malaysia Journal of Society and Space, 12(5), 161-170.

Boland, M., Hogeland, J., \& McKee, G. (2011). Current issues in strategy for agricultural cooperatives. The Magazine of Food, Farm and Resources Issues. $3^{\text {rd }}$ Quarter, 26(3), 14.

Braun, V., \& Clarke, V. 2006. Using thematic analysis in pscychology. Qualitative Research in Psychology, 3, 77-101.

International Cooperative Alliance (ICA) ${ }^{\mathrm{a}}$. (2018). History of the Cooperative Movement. Retrieved from https://www.ica.coop/en/cooperatives/history-cooperative-movement

International Cooperative Alliance (ICA) ${ }^{\mathrm{b}}$. (2018). Cooperative Identity, Values \& Principles. Retrieved from https://www.ica.coop/en/cooperatives/cooperative-identity

International Cooperative Alliance (ICA) ${ }^{\mathrm{c}}$ (2019). Retrieved from https://www.ica.coop/en/ cooperatives/what-is-a-cooperative

Kumar, K. (1990). Utopian thought and communcal practice. Theory and Society. 19, 1-35.

Kumar, V., Wankhede, K.G., \& Gena, H.C. (2015). Role of cooperatives in improving livelihood of farmers on sustainable basis. American Journal of educational Research, 3(10), 12581266.

Mahazril 'Aini Y., Hafizah, H.A.K., \& Zuraini, Y. (2012). Factors affecting cooperatives' performance in relation to strategic planning and members; participation. ProcediaSocial and Behavioral Science, 65(2012), 100-105.

Ojiagu, N.C., Onugu, C., \& Uchenna. 2015. Effects of membership of cooperative organizations and determinants on farmer-members' income in rural Anambra State, Nigeria. International Journal of Scientific \& Technology Research, 4(08), 28-35.

Ortmann, G.F., \& King. R.P. (2007). Agricultural cooperatives 1: History, theory and problems. Agrekon, 46(1), 40-68.

Pathak, R.D., \& Kumar, N. (2005). The key factors contributing towards successful performance of cooperatives in Fiji for building a harmonious society. Network of Asia-Pacific Schools and Institutes of Public Administration and Governance (NAPSIPAG) Annual Conference 2005, Beijing, PRC, 5-7 December 2005.

Sarmila Md. Sum, Zaimah Ramli, Rusyda Ramli, Novel Lyndon, Rosniza Aznie Che Ros, Nur Hanai Mansor, Zaki Aman, Nazirah Jaafar, \& Khairul Anwar Isnin. (2017). Sumbangan koperasi terhadap pembangunan sosial komuniti pekebun kecil sawit. GeografiaMalaysian Journal of Society and Space, 13(3), 19-28.

Somerville, P. (2007). Co-Opetaive Identity. Journal of Co-operative Studies, 40(1), 5-17.

Suraiya Ishak, Ahmad Raflis Che Omar, Mohd Yusof Hussain, Abd. Hair Awang, Novel Lyndon \& Mohd Syafiq Akmal Kasimun. (2016). Menjejaki mekansime kawalan ke atas aktiviti orang tengah dalam rantaian pengeluaran hasil pekebun kecil kelapa sawit di Malaysia. Geografia-Malaysian Journal of Society and Space, 12(4), 46-58. 
Suraiya Ishak, Mohd Yusoff Hussain, Ahmad Raflis Che Omar, Abd. Hair Awang \& Novel Lyndon. (2017). Meneroka refleksi simpati rasional orang tengah dalam rantaian pengeluaran kelapa sawit pekebun kecil. Akademika-Journal of South East Asia Social Sciences and Humanities, 87(2), 45-61.

Suruhanjaya Koperasi Malaysia (SKM). (2018). Laman Web Rasmi. Diambil dari https://www.skm.gov.my/index.php/my/akta-koperasi-1993-pindaan-2007-akta-502

Sushila Devi, R., Nurizah, N., Mohd. Shahron, A. S., Rafedah, J., \& Farahaini, M.H. (2009). Factors influencing the performance of cooperatives in Malaysia: A tentative framework. Malaysian Journal of Co-operative Management, 5, 43-62.

Sushila Devi, R., Nurizah, N., Mohd. Shahron, A. S., Rafedah, J., \& Farahaini, M.H. 2010. Success factors of cooperatives in Malaysia: An exploratory investigation. Malaysian Journal of Co-operative Studies, 6, 1-24.

Torgerson, R.E., Reynolds, B.J., \& Gray, T.W. (1997). Evolution of cooperative thought, theory and purpose. Cooperatives: Their Importance in the Future of the Food and Agricultural System. Food and Agricultural Marketing Consortium, Las Vegas, NV, January 16-17.

Othman, R., embi, R. Abdul Aris, N., Mohd Arif, S.M., Choo, H.C., \& Ismail, N. (2016). Board governance and perfromance: an exploratory study of Malaysian cooperative organziations. Journal of Southeast Asian Research, 2016(2016), 1-12. 